Prepared in cooperation with the U.S. Bureau of Land Management

\title{
Extending Seasonal Discharge Records for Streamgage Sites on the North Fork Fortymile and Middle Fork Fortymile Rivers, Alaska, through Water Year 2020
}

Scientific Investigations Report 2021-5014 
Cover. Upstream view of the Middle Fork Fortymile River near U.S. Geological Survey streamgage 15331000, Middle Fork Fortymile River near mouth near Chicken, Alaska. (Photograph by Heather Best, U.S. Geological Survey, May 19, 2020.) 


\section{Extending Seasonal Discharge Records for Streamgage Sites on the North Fork Fortymile and Middle Fork Fortymile Rivers, Alaska, through Water Year 2020}

By Janet H. Curran

Prepared in cooperation with the U.S. Bureau of Land Management

Scientific Investigations Report 2021-5014 


\section{U.S. Geological Survey, Reston, Virginia: 2021}

For more information on the USGS - the Federal source for science about the Earth, its natural and living resources, natural hazards, and the environment—visit https://www.usgs.gov or call 1-888-ASK-USGS.

For an overview of USGS information products, including maps, imagery, and publications, visit https://store.usgs.gov/.

Any use of trade, firm, or product names is for descriptive purposes only and does not imply endorsement by the U.S. Government.

Although this information product, for the most part, is in the public domain, it also may contain copyrighted materials as noted in the text. Permission to reproduce copyrighted items must be secured from the copyright owner.

Suggested citation:

Curran, J.H., 2021, Extending seasonal discharge records for streamgage sites on the North Fork Fortymile and Middle Fork Fortymile Rivers, Alaska, through water year 2020: U.S. Geological Survey Scientific Investigations Report 2021-5014, 11 p., https://doi.org/10.3133/sir20215014.

ISSN 2328-0328 (online) 


\section{Contents}

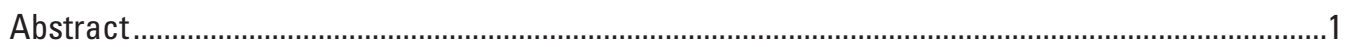

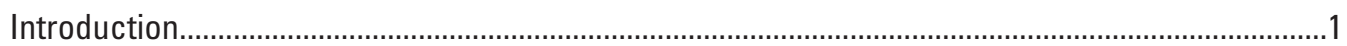

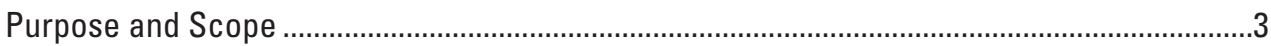

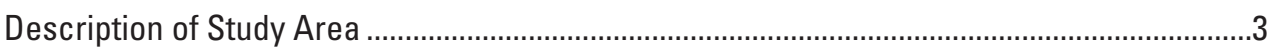

Basin Streamflow Conditions During the Concurrent Period.....................................................4

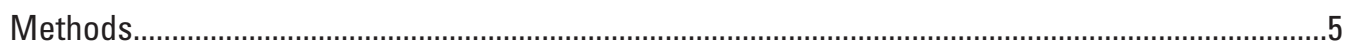

Selection of Seasons of Analysis..........................................................................................

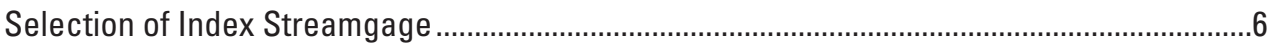

Record Extension Technique ...................................................................................................

Extended Daily Mean Discharge Records and Error Analysis...........................................................

Comparison of Observed and Estimated Records...............................................................

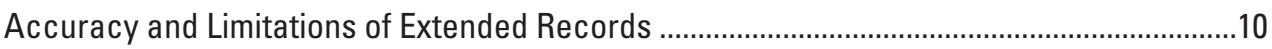

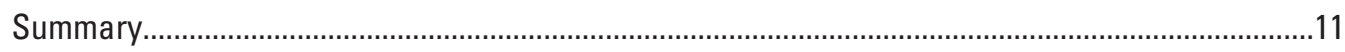

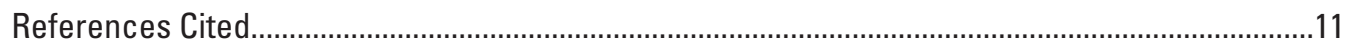

\section{Figures}

1. Map showing locations of study and index streamgages in the Fortymile River Basin, Alaska.

2. Hydrograph showing daily mean discharges for U.S. Geological Survey streamgages 15330000 (North Fork Fortymile River above Middle Fork near Franklin, Alaska); 15331000 (Middle Fork Fortymile River near mouth near Chicken, Alaska); and 15348000 (Fortymile River near Steele Creek, Alaska), water years 2019-20.

3. Flow duration curves for selected periods for U.S. Geological Survey streamgage 15348000 (Fortymile River near Steele Creek, Alaska).

4. Plot of concurrent observed discharge for the study seasons in water year 2019 and water year 2020 and the maintenance of variance extension type 3 (MOVE.3) regression line at U.S. Geological Survey streamgages (A) 15330000 (North Fork Fortymile River above Middle Fork near Franklin, Alaska) and 15348000 (Fortymile River near Steele Creek, Alaska), and (B) 15331000 (Middle Fork Fortymile River near mouth near Chicken, Alaska) and 15348000 (Fortymile River near Steele Creek, Alaska)

5. Plots of observed and estimated discharges for the concurrent period of record in 2019 and 2020 used in analysis at U.S. Geological Survey streamgages (A) 15330000 (North Fork Fortymile River above Middle Fork near Franklin, Alaska), and (B) 15331000 (Middle Fork Fortymile River near mouth near Chicken, Alaska) 


\section{Tables}

1. Drainage area and period of discharge record for study and index streamgages in the Fortymile River Basin, Alaska, through water year 2020..

2. Correlation coefficients (Pearson's $r$ ) between logarithms of daily mean discharge at study and index streamgages in the Fortymile River Basin, Alaska .............8

3. Summary statistics of the concurrent observed and estimated daily mean discharge records at two study streamgages in the Fortymile River Basin, Alaska.........8

4. Root mean square error and modified Nash-Sutcliffe efficiency coefficients for MOVE.3 regression models at two study streamgages in the Fortymile River Basin, Alaska

\section{Conversion Factors}

U.S. customary units to International System of Units

\begin{tabular}{|c|c|c|}
\hline Multiply & By & To obtain \\
\hline \multicolumn{3}{|c|}{ Length } \\
\hline inch (in.) & 2.54 & centimeter $(\mathrm{cm})$ \\
\hline inch (in.) & 25.4 & millimeter $(\mathrm{mm})$ \\
\hline foot $(\mathrm{ft})$ & 0.3048 & meter $(\mathrm{m})$ \\
\hline mile (mi) & 1.609 & kilometer (km) \\
\hline \multicolumn{3}{|c|}{ Area } \\
\hline square mile $\left(\mathrm{mi}^{2}\right)$ & 259.0 & hectare (ha) \\
\hline square mile $\left(\mathrm{mi}^{2}\right)$ & 2.590 & square kilometer $\left(\mathrm{km}^{2}\right)$ \\
\hline \multicolumn{3}{|c|}{ Volume } \\
\hline cubic foot $\left(\mathrm{ft}^{3}\right)$ & 28.32 & cubic decimeter $\left(\mathrm{dm}^{3}\right)$ \\
\hline cubic foot $\left(\mathrm{ft}^{3}\right)$ & 0.02832 & cubic meter $\left(\mathrm{m}^{3}\right)$ \\
\hline \multicolumn{3}{|c|}{ Flow rate } \\
\hline cubic foot per second $(\mathrm{ft} 3 / \mathrm{s})$ & 0.02832 & cubic meter per second $\left(\mathrm{m}^{3} / \mathrm{s}\right)$ \\
\hline
\end{tabular}

Temperature in degrees Fahrenheit $\left({ }^{\circ} \mathrm{F}\right)$ may be converted to degrees Celsius $\left({ }^{\circ} \mathrm{C}\right)$ as follows:

$$
{ }^{\circ} \mathrm{C}=\left({ }^{\circ} \mathrm{F}-32\right) / 1.8
$$

\section{Datums}

Vertical coordinate information is referenced to the North American Vertical Datum of 1988 (NAVD 88).

Horizontal coordinate information is referenced to the North American Datum of 1983 (NAD 83). Altitude, as used in this report, refers to distance above the vertical datum. 


\section{Abbreviations}

AEP annual exceedance probability

MOVE.3 maintenance of variance extension type 3

NAD 83 North American Datum of 1983

NAVD 88 North American Vertical Datum of 1988

NSE Nash-Sutcliffe efficiency coefficient

NWIS National Water Information System

RMSE root mean square error

USGS U.S. Geological Survey

WY water year 



\title{
Extending Seasonal Discharge Records for Streamgage Sites on the North Fork Fortymile and Middle Fork Fortymile Rivers, Alaska, through Water Year 2020
}

\author{
By Janet H. Curran
}

\section{Abstract}

Daily mean discharge records are needed for management of selected streams in the Fortymile River Basin. The U.S. Geological Survey, in cooperation with the U.S. Bureau of Land Management, updated a technique for estimating seasonal (partial year) discharge at two short-record streamgage sites in the basin and evaluated the accuracy of the estimates. Daily mean discharge values were estimated for May 15-September 30, 1976-82 and 2006-18, for U.S. Geological Survey streamgage sites 15330000 (North Fork Fortymile River above Middle Fork near Franklin, Alaska) and 15331000 (Middle Fork Fortymile River near mouth near Chicken, Alaska). Relations between discharge for each study streamgage and an index streamgage on the main-stem Fortymile River (15348000, Fortymile River near Steele Creek, Alaska) for concurrent seasonal periods in 2019 and 2020 were developed using the maintenance of variance extension type 3 (MOVE.3) record extension technique. The MOVE. 3 regressions were used to estimate daily mean discharges at the study streamgage sites for the selected season for the longer period of record of the index streamgage. Additionally, estimated records were generated from the regressions for the concurrent seasonal periods to evaluate the accuracy of the record extension techniques. The modified Nash-Sutcliffe efficiency coefficients for the estimated records were 0.53 for the North Fork Fortymile River (15330000) and 0.70 for the Middle Fork Fortymile River (15331000) streamgages.

\section{Introduction}

Daily mean discharge forms the basis of analysis for a wide variety of water resource management needs, including engineering design, environmental assessment, and legal agreement of water use. Many agency agreements and legal statutes rely on discharge statistics that can quantify historical water availability and express wetted channel conditions. Discharge statistics can be determined from data collected at U.S. Geological Survey (USGS) streamgages and are most representative when compiled for daily mean discharge records that include annual- to decadal-scale variations. However, long records are unavailable for many locations where such information is needed. To account for longer-term natural variations at a shorter-record location, record extension techniques can be used to estimate discharge. Record extension relates discharge at a site of interest to concurrent discharge at a streamgage having a longer period of record, referred to as an "index streamgage" (Hirsch, 1979; Hirsch, 1982). That relation can then be applied to the longer period of record for the index streamgage to estimate a discharge record for the study streamgage. Record extension requires a concurrent period of record with a closely correlated index streamgage and a longer period of record for the index streamgage from which to estimate discharge for the shortrecord streamgage.

Within the Fortymile River Basin in east-central Alaska, the USGS collected discharge data for part of the warm hydrological season (the period outside the cold-induced low-flow period) in 2019 and 2020 at two study streamgages, 15330000 (North Fork Fortymile River above Middle Fork near Franklin, Alaska) and 15331000 (Middle Fork Fortymile River near mouth near Chicken, Alaska) (fig. 1). Longer estimates of seasonal (partial year) daily mean discharge for these study sites are needed for management of the streams. Using 2019 data, the USGS estimated seasonal daily mean discharge records for the study streamgages using streamgage 15348000 (Fortymile River near Steele Creek, Alaska; fig. 1) as an index streamgage (Curran, 2020). The USGS conducted the study summarized in this report in cooperation with U.S. Bureau of Land Management in order to develop updated estimates of seasonal daily mean discharge records for the study streamgage sites using 2019 and 2020 discharge data. 


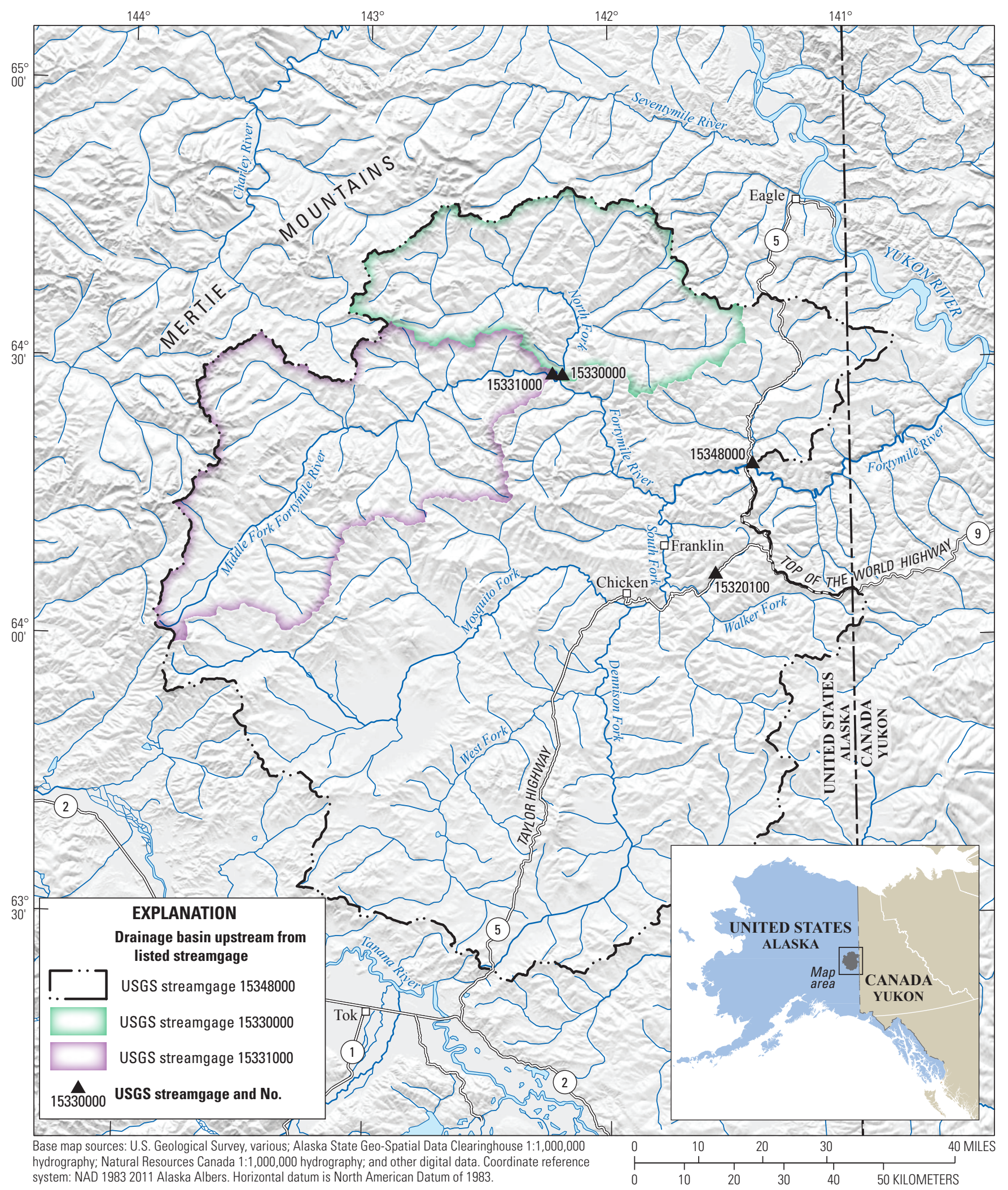

Figure 1. Locations of study and index streamgages in the Fortymile River Basin, Alaska. USGS, U.S. Geological Survey. 


\section{Purpose and Scope}

This report describes the development of an updated technique for estimating daily mean discharge for two streamgage sites of interest in the Fortymile River Basin using the maintenance of variation extension type 3 (MOVE.3) record extension technique. This report updates streamflow estimation techniques described in Curran (2020) and supersedes that report. Because the technique for estimating daily mean discharge described in Curran (2020) was based on 1 year of seasonal discharge data and that year had relatively low discharges, this study independently re-evaluated all aspects of the analysis with an additional year of seasonal data. It documents the selection of a season of analysis and an index streamgage, presents estimates of historical daily mean discharge for an extended period of record, and presents an evaluation of the accuracy of the estimated records. Within the limitations discussed, the results of this study are suitable for use in preparation of discharge statistics, including the number of days that daily mean discharge falls between a higher and lower discharge threshold during the season used in this report.

\section{Description of Study Area}

The Fortymile River is a tributary to the Yukon River located about 150 miles (mi) east of Fairbanks in east-central Alaska and Canada (fig. 1). The river drains more than 6,000 square miles $\left(\mathrm{mi}^{2}\right)$ and contains numerous tributaries. The two largest tributaries, the North Fork and South Fork Fortymile Rivers, join to form the main-stem Fortymile River northeast of Chicken and the abandoned Franklin townsite and upstream of the Taylor Highway (fig. 1). Farther upstream, the Middle Fork Fortymile River, (hereinafter, "Middle Fork"), which drains the northwest part of the basin, joins the North Fork Fortymile River (hereinafter, "North Fork"). For convenience, this report references the USGS streamgages on these rivers by their USGS identification number and truncated streamgage name-North Fork Fortymile River above Middle Fork near Franklin, Alaska (15330000; North Fork); Middle Fork Fortymile River near mouth near Chicken, Alaska (15331000; Middle Fork); and Fortymile River near Steele Creek, Alaska (15348000; Fortymile).

The Fortymile River Basin includes the hilly terrain of the Mertie Mountains, which range in altitude from about 3,000 to 6,000 feet along the western and northern parts of the basin, and gently sloped flats containing extensive wetlands in the southern part of the basin. Wetlands also occupy the wide valley bottom of the upper reaches of the Middle Fork. The Fortymile River Basin has a continental climate characterized by cold, dry winters and warm summers. For the part of the basin draining to 15348000 (Fortymile), the mean January temperature for 1971-2000 (Gibson, 2009a) was -9 degrees Fahrenheit, and the mean July temperature was 54 degrees Fahrenheit. For 1971-2000 there was an annual average of 15 inches of precipitation (Gibson, 2009b), which included snow in winter. Basin average precipitation is highest in the summer months of June-August.

Streamgage 15330000 (North Fork) is located on the North Fork about 0.4 mi upstream of the confluence with the Middle Fork and includes discharge from nearly all the North Fork basin upstream of the confluence. Streamgage 15331000 (Middle Fork) is located on the Middle Fork about $1.7 \mathrm{mi}$ upstream of the confluence and includes discharge from the entire Middle Fork basin upstream of the confluence except for a small area near the Middle Fork mouth. Hydrographs for these two study streamgages and 15348000 (Fortymile River) during the concurrent period in water year ${ }^{1}$ (WY) 2019 and 2020 show patterns of discharge rising abruptly and then falling over several days that generally represent discharge response to precipitation (fig. 2). Despite the proximity of the study streamgages, slight differences appear in the timing of their discharge patterns. Discharge at 15330000 (Middle Fork) more closely matched the daily- to weekly-scale rising and falling patterns of 15348000 (Fortymile) than did discharge at 15331000 (North Fork). The crest of some of these fluctuations arrived earlier at 15330000 (North Fork) than at 15331000 (Middle Fork) or 15348000 (Fortymile) in 2019, motivating the application of an offset to index streamgage data for development of the 15330000 (North Fork) model in Curran (2020), but this pattern was not consistently observed in the 2020 data, and no offset was considered. Basin differences, including topography, the spatial distribution of wetlands, drainage area, or stream length, or differences in storm tracks, could at least partly explain the differences in short-term fluctuations in discharge.

\footnotetext{
${ }^{1} \mathrm{~A}$ water year is defined as the 12-month period from October 1 to September 30 of the following year and is named for the calendar year in which it ends. Thus, the year ending September 30, 2020, is "water year 2020."
} 


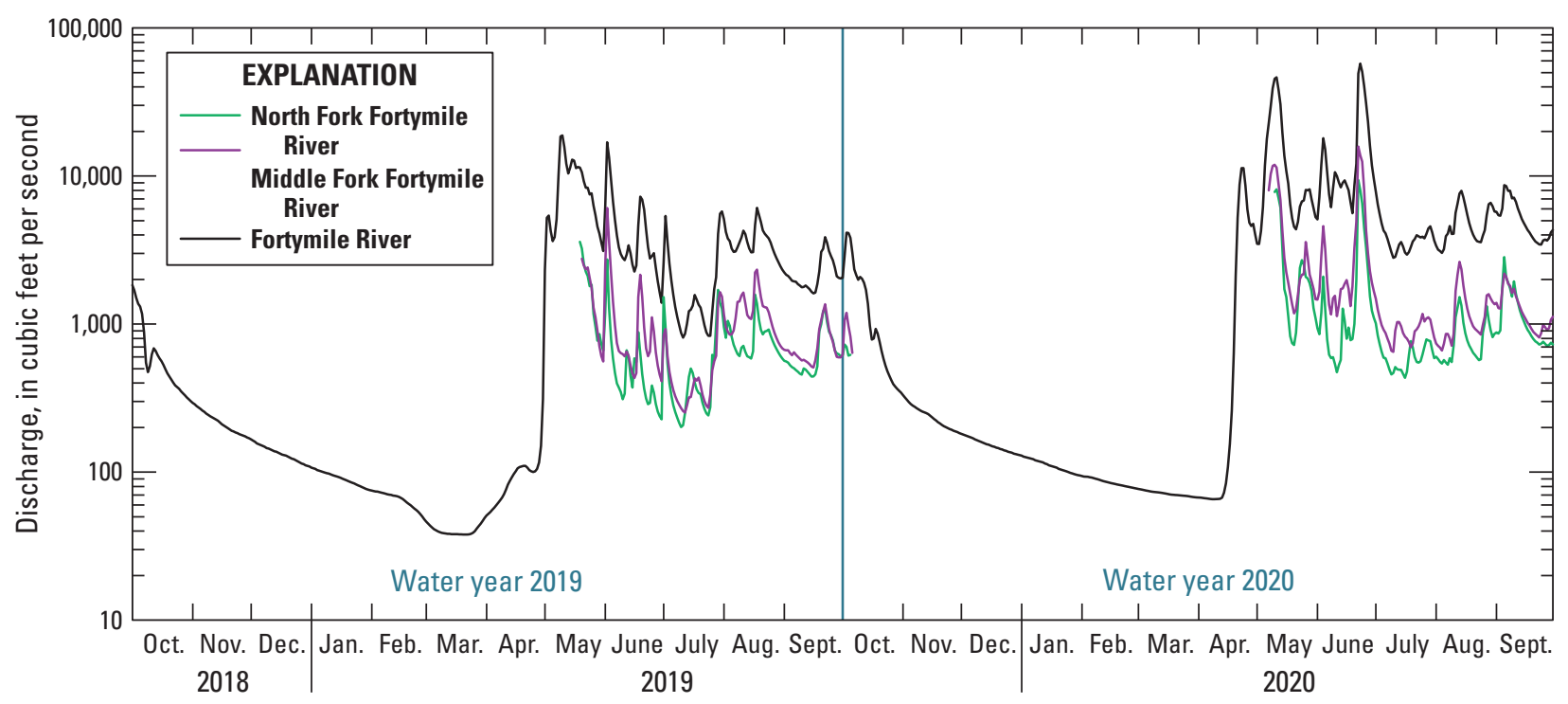

Figure 2. Daily mean discharges for U.S. Geological Survey streamgages 15330000 (North Fork Fortymile River above Middle Fork near Franklin, Alaska); 15331000 (Middle Fork Fortymile River near mouth near Chicken, Alaska); and 15348000 (Fortymile River near Steele Creek, Alaska), water years 2019-20. A water year is defined as the 12-month period from 0ctober 1 to September 30 of the following year and is named for the calendar year in which it ends. Thus, the year ending September 30 , 2020 , is "water year 2020."

\section{Basin Streamflow Conditions During the Concurrent Period}

Data collection for the study streamgages occurred in 2 years that had different discharge properties, on average, across the Fortymile River Basin. Mean discharge during the concurrent seasonal period was lower in 2019 than in 2020 at the study streamgages and at 15348000 (Fortymile) (fig. 2). A spatially and temporally broader context for these relative discharge magnitudes can be inferred from two longer-record streamgages in the Fortymile River Basin (fig. 1): 15348000 (Fortymile), which has a relatively large drainage area $(5,850$ $\mathrm{mi}^{2}$ ) and 15320100 (Wade Creek tributary near Chicken, Alaska), a streamgage on the eastern side of the basin that has a much smaller drainage area $\left(4.2 \mathrm{mi}^{2}\right)$. In 22 years of daily mean discharge record (WY 1976-82 and 2006-20) at 15348000 (Fortymile), the mean annual discharge for WY 2019 was the third smallest and the mean annual discharge for WY 2020 was the second largest. In 15 years of daily mean discharge record (WY 2006-20) at streamgage 15320100 (Wade Creek tributary near Chicken, Alaska), WY 2019 had the 6th-smallest mean annual discharge and WY 2020 had the largest. Additionally, flow duration curves compiled for seasonal nonconcurrent and concurrent periods at 15348000 (Fortymile; fig. 3) show that discharges across nearly all exceedance probabilities were smaller in WY 2019 than in the noncurrent period and larger in WY 2020 than in the nonconcurrent period. The combination of the relatively low WY 2019 and relatively high WY 2020 discharges for the concurrent period of WY 2019-20 created a flow duration curve that much more closely matched the curve for the nonconcurrent period than did the curves for the individual years. 


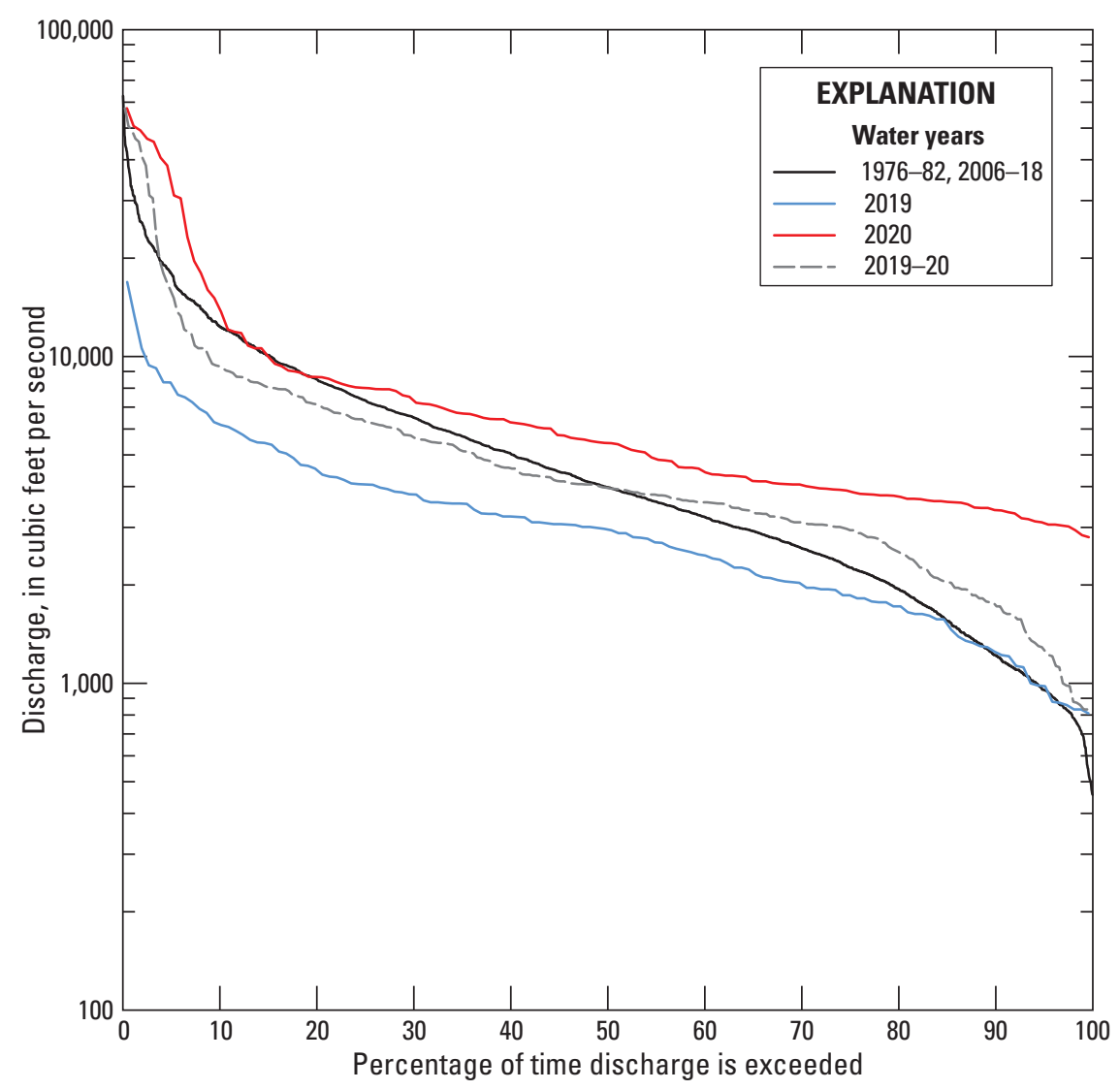

Figure 3. Flow duration curves for selected periods for U.S. Geological Survey streamgage 15348000 (Fortymile River near Steele Creek, Alaska). The respective seasons used are May 15-September 30 for water years (WY) 1976-82 and 2006-18, May 20-September 30 for WY 2019, and May 10-September 30 for WY 2020.

\section{Methods}

Record extension was conducted for a selected season using an index streamgage that met selection criteria and a record extension technique developed for use with hydrologic data, as described in the following subsections. Hydrologic data used in the analyses consisted of daily mean discharge obtained from the National Water Information System (NWIS; U.S. Geological Survey, 2020). For correlation and record extension analysis, daily mean discharge data were transformed using a common logarithm to improve data distribution. All analyses used the R language and programming environment version 4.0.3 (R Core Team, 2020).

\section{Selection of Seasons of Analysis}

To improve the accuracy of the estimated records, the season for developing record extension techniques and the season for extending records were selected from periods likely to have similar streamflow-generating processes. The warm hydrological season for the study and index streamgages can be described as extending from the initial flush of snowmeltdriven discharges in spring, which are often the highest discharges of the year, to the steep decline in discharge associated with freezing conditions in autumn. The seasons of analysis were chosen to be as long as possible within this warm hydrological season while avoiding days at the beginning and end of the warm season likely to have transitional processes. Selection considered the range of available data for the study streamgages, the range of the warm hydrological season at the study and index streamgages, and the convenience of the dates for data management. 
For developing a record extension technique, May 20-September 30, 2019, and May 10-September 30, 2020, were selected as the seasons of analysis. The start dates of the selected seasons were chosen as the first concurrent day of daily mean discharge record at the two study streamgages in each year using patterns in observed study and index streamgage discharges (fig. 2) to ensure the dates met study criteria. The end of the water year (September 30) was near the end of the hydrological warm season and formed a convenient end date for the study seasons. Extra days of study streamgage record outside each chosen season were ignored for the convenience of a common study season between the two study streamgages. The season of May 15-September 30 was selected for extending records. Inspection of discharge patterns for the longer period of record at the index streamgage on the main-stem Fortymile River shows that this season has consistently represented a subset of the warm hydrological season.

\section{Selection of Index Streamgage}

For each study streamgage, one or more longer-record streamgages were sought to serve as single or composite index streamgages for extending daily mean discharge. In the previous study through WY 2019 (Curran, 2020), streamgages considered as potential index streamgages consisted of USGS streamgages in and near the Fortymile River Basin that had a period of record overlapping the study streamgage records and a longer period of record outside the study streamgage period of record. For the study summarized in this report, this selection process was repeated to include additional study streamgage data (table 1). Index streamgage selection criteria included proximity to the study streamgage, the strength and linearity of the correlation of daily mean discharges with concurrent daily mean discharges at the study streamgage, hydrologic similarity to the study streamgage over a range of low-high discharges, and the length of record available for extension beyond the concurrent record. Streamgage 15348000 (Fortymile; fig. 1; table 1) was selected as the index streamgage for both study streamgages.

Log-scale scatterplots of concurrent daily mean discharge for the study and index streamgage (fig. 4) were examined for linearity, scatter, and outliers. Log-scale plots of daily mean discharge at study and index streamgages for the concurrent period (fig. 2) were examined for similarity in seasonal discharge patterns, and log-scale plots of daily mean discharge for the full index streamgage period of record were examined for annual variability in seasonal discharge patterns. Pearson's correlation coefficients $(r)$ computed for the logarithms of daily mean discharge at the study streamgage sites and the index streamgage site (table 2) were 0.842 for 15330000 (North Fork) and 0.950 for 15331000 (Middle Fork).

\section{Record Extension Technique}

Record extension is a technique for estimating discharge for an extended historical period at a study stream location using a relation between observed discharge at the study stream location and one or more index stream locations. Techniques for extending discharge records usually employ some form of linear regression to establish the relation between concurrent observed discharge at the study and index locations or streamgages. Although ordinary least squares regression can be used, the line of organic correlation method implemented by maintenance of variance extension (MOVE) techniques provides a better estimate of extended discharge records by seeking to maintain the variance of the observed study streamgage discharges in the estimated discharges (Hirsch, 1982; Vogel and Stedinger, 1985; Helsel and Hirsch, 2002). The MOVE. 3 regression incorporates the mean and standard deviation of the concurrent discharges and the mean and standard deviation of the nonconcurrent index streamgage discharges (Vogel and Stedinger, 1985; Granato, 2009) and results in an equation that uses the logarithms of daily mean discharge, which then can be rewritten in the form of the equation for a straight line:

$$
\log _{10} Q=m\left(\log _{10} Q_{\text {index }}\right)+b
$$

where

$$
\begin{gathered}
Q \quad \begin{array}{c}
\text { is the estimated daily mean discharge at the } \\
\text { study streamgage, in cubic feet per second } \\
(\mathrm{ft} 3 / \mathrm{sec}),
\end{array} \\
\begin{array}{c}
\text { is the intercept of the regression line, } \\
Q_{\text {index }} \\
\text { is the observed daily mean discharge at the } \\
\text { index streamgage, in } \mathrm{ft} 3 / \mathrm{s} \text {, and }
\end{array} \\
m \quad \text { is the slope of the regression line. }
\end{gathered}
$$

To simplify for use extending daily mean discharge in arithmetic units, eq. 1 can be transformed from logarithmic to arithmetic units to produce the following:

$$
Q=10^{b} Q_{\text {index }}^{m}
$$

The MOVE. 3 regressions for the study streamgages were developed using an R script that computed correlations, generated the MOVE. 3 equations, and estimated daily discharge for the study streamgages (Williams-Sether and Wheeling, 2020, appendix 2). Because the script was coded for use with multiple index streamgages, separate runs were conducted with each study streamgage paired with the index streamgage in order to enforce the use of the selected index streamgage. The resulting equations for estimating daily mean discharge at the study streamgages using 15348000 (Fortymile) are:

and

$$
Q_{15330000}=0.5772 Q_{15348000} 0.8640
$$

$$
Q_{15331000}=0.4547 Q_{15348000^{0.9316}}
$$

where

the subscripts for $Q$ are the USGS streamgage numbers. 
Table 1. Drainage area and period of discharge record for study and index streamgages in the Fortymile River Basin, Alaska, through water year 2020.

[Abbreviations: USGS, U.S. Geological Survey; $\mathrm{mi}^{2}$, square mile]

\begin{tabular}{|c|c|c|c|c|}
\hline \multirow[b]{2}{*}{$\begin{array}{l}\text { USGS streamgage } \\
\text { number }\end{array}$} & \multirow[b]{2}{*}{ Streamgage name } & \multirow[b]{2}{*}{$\begin{array}{l}\text { Drainage area } \\
\qquad\left(\mathrm{mi}^{2}\right)\end{array}$} & \multicolumn{2}{|c|}{ Period of discharge record } \\
\hline & & & Month and day & Water years \\
\hline 15330000 & $\begin{array}{l}\text { North Fork Fortymile River above } \\
\text { Middle Fork near Franklin, Alaska }\end{array}$ & 750 & $\begin{array}{c}\text { May } 19-\text { September } 30 \\
\text { October } 1-5 \text {, May } 10- \\
\text { September } 30\end{array}$ & $\begin{array}{l}2019 \\
2020\end{array}$ \\
\hline \multicolumn{5}{|c|}{ Index streamgage } \\
\hline 15348000 & $\begin{array}{l}\text { Fortymile River near Steele Creek, } \\
\text { Alaska }\end{array}$ & 5,850 & October 1-September 30 & 1976-82, 2006-20 \\
\hline
\end{tabular}
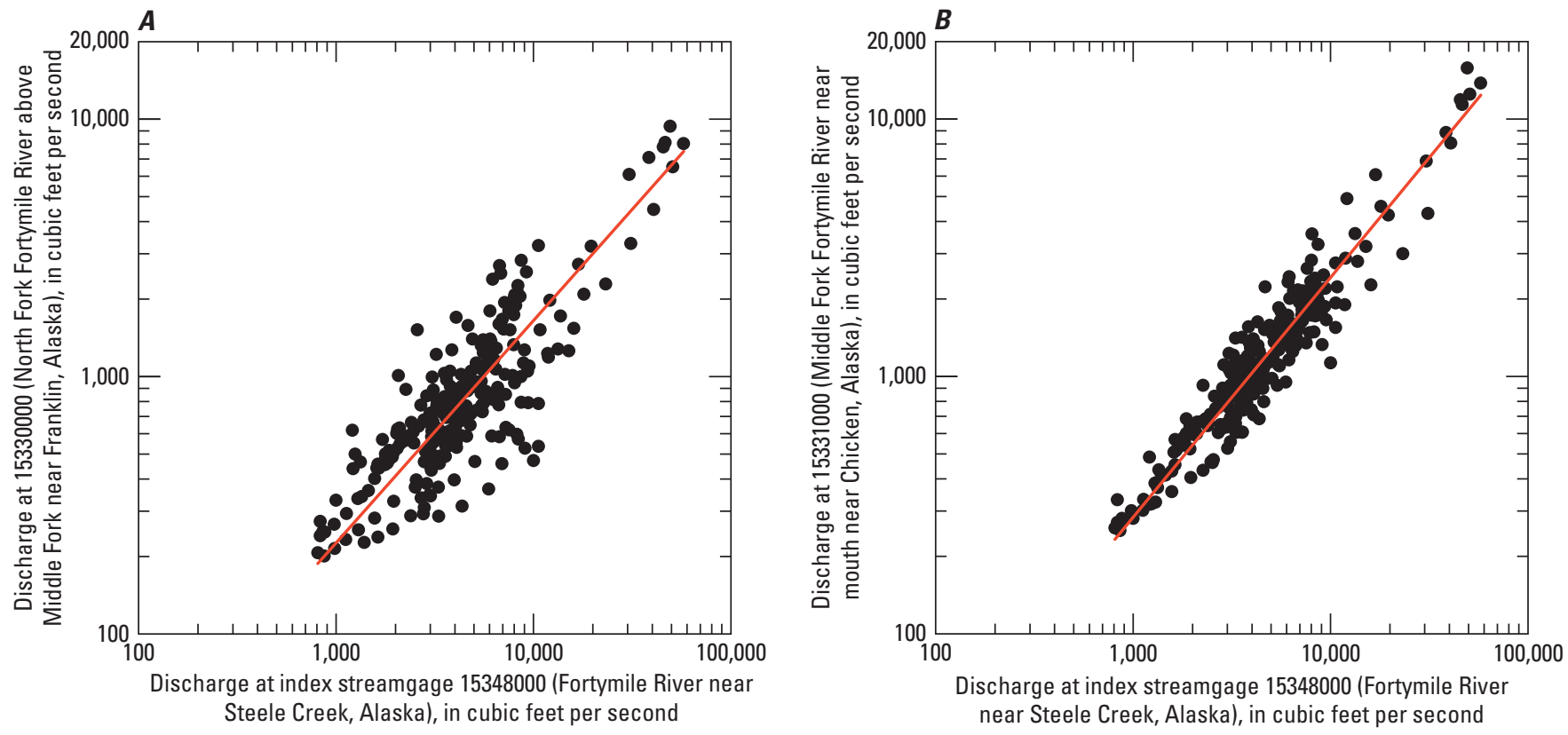

Figure 4. Concurrent observed discharge for the study seasons in water year (WY) 2019 and WY 2020 and the maintenance of variance extension type 3 (MOVE.3) regression line at U.S. Geological Survey streamgages (A) 15330000 (North Fork Fortymile River above Middle Fork near Franklin, Alaska) and 15348000 (Fortymile River near Steele Creek, Alaska), and (B) 15331000 (Middle Fork Fortymile River near mouth near Chicken, Alaska) and 15348000 (Fortymile River near Steele Creek, Alaska). 
Table 2. Correlation coefficients (Pearson's $r$ ) between logarithms of daily mean discharge at study and index streamgages in the Fortymile River Basin, Alaska.

[Abbreviation: USGS, U.S. Geological Survey]

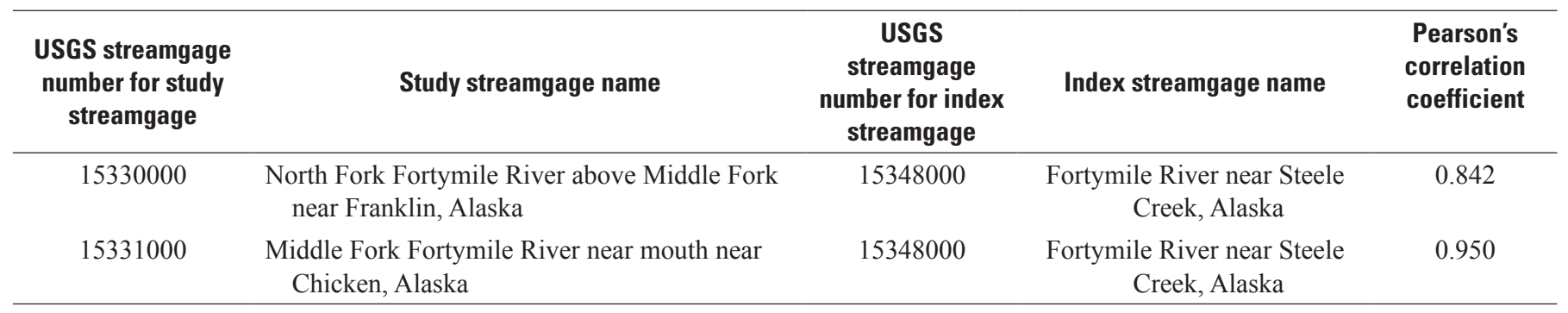

Seasonal record extension using equations 3 and 4 is only intended for use with index streamgage values $\left(Q_{15348000}\right)$ that occurred during the study season May 15-September 30. Outside these date ranges, different processes might govern discharge, and the relation between study and index streamgage discharges might vary. Particularly, very low discharges from winter conditions and very high discharges from snowmelt conditions before the study season are not represented by the observed discharges used to develop these equations.

\section{Extended Daily Mean Discharge Records and Error Analysis}

The MOVE. 3 regressions in equations 3 and 4 were used to estimate daily mean discharge at the respective study streamgages for May 15-September 30 for the nonconcurrent period of record at the index streamgage, 1976-82 and 2006-18, and for the concurrent period of record in 2019-20 used to establish the regression equations. The regression estimates for the concurrent period in 2019-20 were used to compare to the observed discharges to compute measures of accuracy. The estimated records are available in a USGS data release at https://doi.org/10.5066/P9VCAOEZ (Curran, 2021). The estimated extended record (the period through 2018) can be merged with the observed data available from NWIS (USGS, 2020) to form a composite dataset. If a complete record for May 15-September 30 is needed for 2019-20, the missing days prior to data collection in 2019 can be estimated for the respective study streamgages from equations 3 and 4 .

\section{Comparison of Observed and Estimated Records}

The fit of the estimated records to the concurrent observed records varied across the range of discharges, as can be expected from the variability of the scatter of observed study and index streamgage data (fig. 4). The mean value of the estimated discharges for the concurrent period of record was within 4 percent or less of the mean value of the observed discharges for the concurrent period of record for each streamgage (table 3). An equivalent comparison is that the estimated total volume of discharge for the concurrent period of record was within 4 percent or less of the observed total volume of discharge. The fit of the study streamgage data to the index streamgage data (fig. 4) varied the most at mid-range values for 15330000 (North Fork). The regression equations underestimated the smallest and largest discharges for both study streamgages (fig. 4).

Table 3. Summary statistics of the concurrent observed and estimated daily mean discharge records at two study streamgages in the Fortymile River Basin, Alaska.

[Abbreviations: USGS, U.S. Geological Survey; ft3/s, cubic feet per second]

\begin{tabular}{|c|c|c|c|c|c|c|c|}
\hline \multirow{3}{*}{$\begin{array}{l}\text { Study USGS } \\
\text { streamgage } \\
\text { number }\end{array}$} & \multirow{3}{*}{ Study streamgage name } & \multicolumn{6}{|c|}{ Daily mean discharge (ft3/s) } \\
\hline & & \multicolumn{2}{|c|}{ Mean } & \multicolumn{2}{|c|}{ Median } & \multicolumn{2}{|c|}{ Standard deviation } \\
\hline & & Observed & Estimated & Observed & Estimated & Observed & Estimated \\
\hline 15331000 & $\begin{array}{l}\text { Middle Fork Fortymile River } \\
\text { near mouth near Chicken, } \\
\text { Alaska }\end{array}$ & 1,500 & 1,470 & 1,030 & 1,020 & 1,910 & 1,670 \\
\hline
\end{tabular}


Observed and estimated discharges were plotted as a hydrograph of daily means (fig. 5) to further examine their fit. For 2019, MOVE.3 regressions generally overestimated discharges early in the season and underestimated discharges later in the season (fig. 5). For 2020, no widespread seasonal pattern of over- or under-estimation was apparent. The seasonal and interannual variation in the fit of the estimated discharges could be related to basin-specific factors such as a difference in runoff-generating processes across the season between basins or uneven spatial distribution of rainfall, but investigation of these differences was beyond the scope of this study.
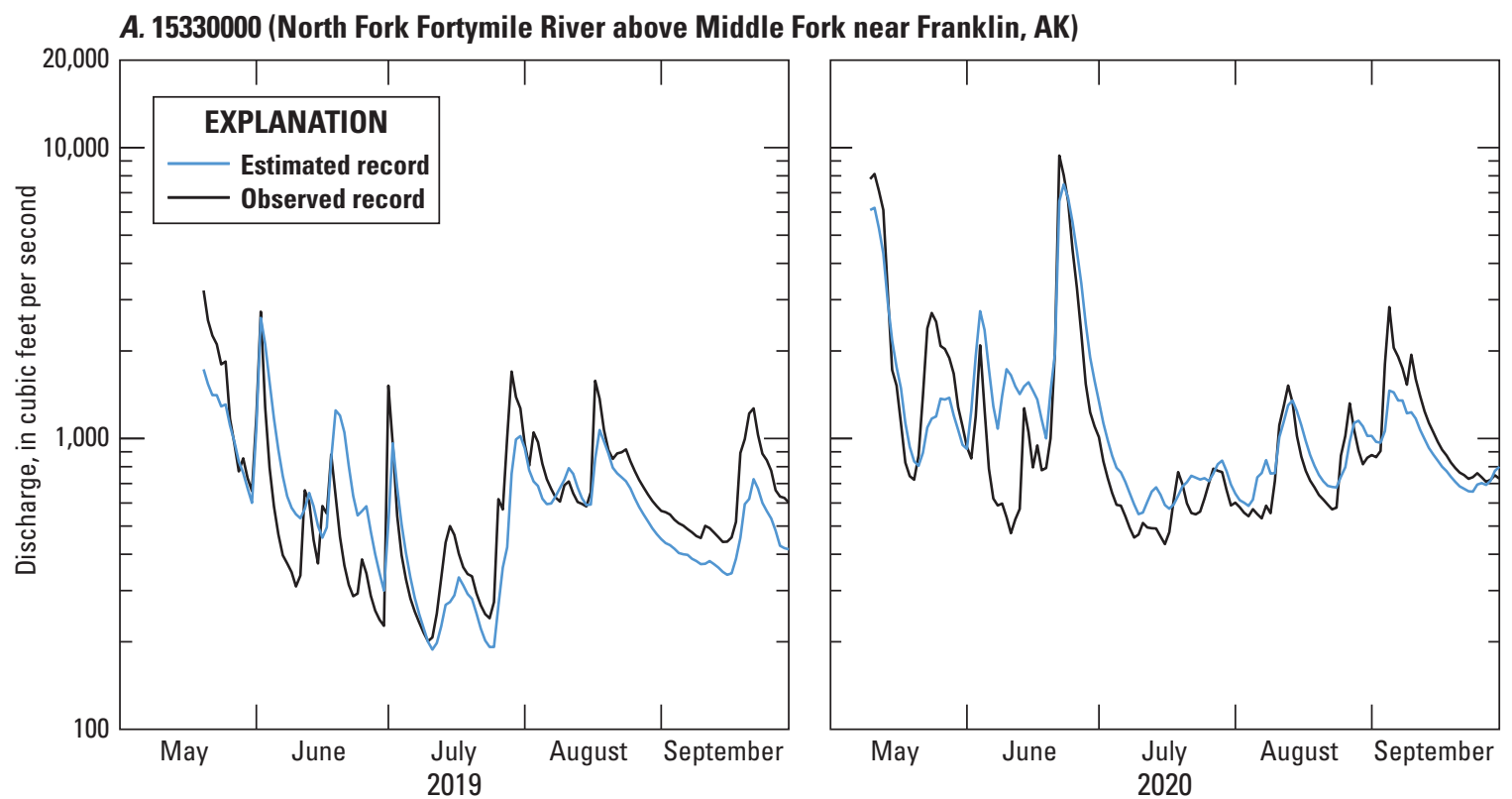

B. 15331000 (Middle Fork Fortymile River near mouth near Chicken, AK)
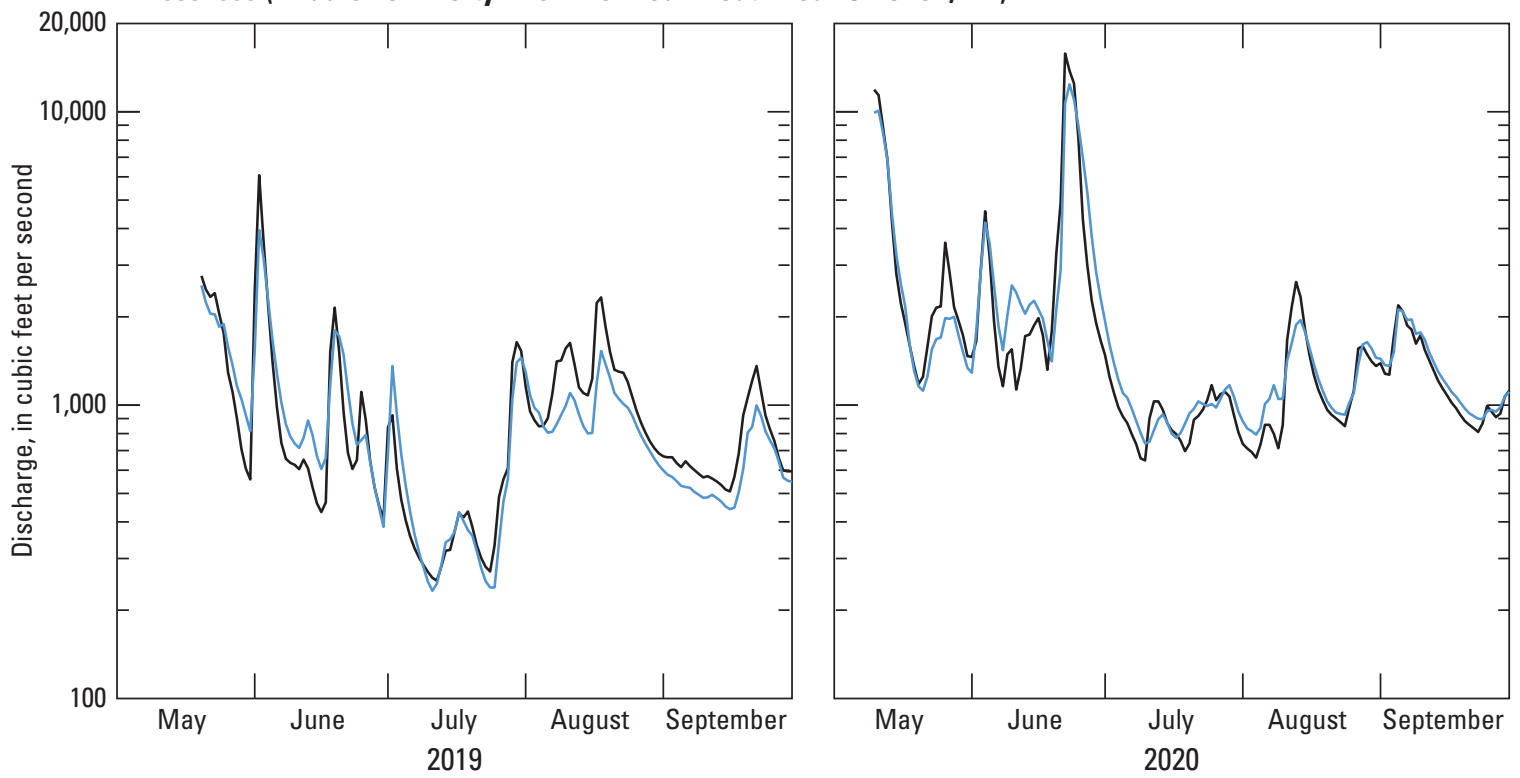

Figure 5. Observed and estimated discharges for the concurrent period of record in 2019 and 2020 used in analysis at U.S. Geological Survey streamgages (A) 15330000 (North Fork Fortymile River above Middle Fork near Franklin, Alaska), and (B) 15331000 (Middle Fork Fortymile River near mouth near Chicken, Alaska). 


\section{Accuracy and Limitations of Extended Records}

The fit of the MOVE. 3 regression models and the accuracy of the predicted records were evaluated using the root mean square error (RMSE) and the modified NashSutcliffe efficiency coefficient (NSE). The RMSE between the observed discharge used to develop the model and the concurrent predicted discharge is a common measure of accuracy. The RMSE is the mean of the absolute distance between the observed and estimated discharges and is lower for models that have a better fit. As for other measures of accuracy computed using the square of the difference between observed and estimated discharges (Krause and others, 2005), the RMSE is sensitive to variations in fit at the largest discharges. To address the disproportionate effect of the addition of larger discharges to the dataset in 2020, the RMSE was computed using log-transformed values for the observed and estimated discharges. The RMSE values for 15330000 (North Fork) and 15331000 (Middle Fork) models are shown in table 4. For the model developed for data through WY 2019, the recomputed RMSEs using log-transformed values for the estimated discharges from appendix 1 of Curran (2020) were 0.15 for 15330000 (North Fork) and 0.10 for 15331000 (Middle Fork) models.

The modified NSE provides a measure of the predictive ability of a model (Legates and McCabe, 1999). Computed from the observed and estimated discharges for the study streamgage, the modified NSE ranges from 1 (for a perfect fit of modeled to observed data) to minus infinity (for a model having no predictive ability). A modified NSE of 0 indicates that the mean of the observed data is as good a predictor as the model. The modified NSE is computed as:

$$
\text { Modified NSE }=1-\frac{\sum_{i=1}^{a}\left|Y_{i}-Y_{p}\right|}{\sum_{i=1}^{n}\left|Y_{i}-\bar{Y}\right|}
$$

where

$n$ is the number of measurements,

$Y_{i}$ is the $i$ th observed daily mean discharge,

$Y_{p}$ is the estimated daily mean discharge

and

$\bar{Y}$ is the average of the observed daily mean discharges.
Because the modified form of the NSE does not use the square of the difference parameters (observed minus estimated and observed minus average), it addresses the concern of sensitivity to the largest discharges (Krause and others, 2005). The modified NSE was computed without a transform of the observed and estimated discharges. The modified NSE for 15330000 (North Fork) and 15331000 (Middle Fork) MOVE.3 models are shown in table 4.

In addition to measures of accuracy, the user should consider the limitations of the data used to develop equations when using estimates to construct discharge statistics. Estimating discharge for nonconcurrent index streamgage discharges greater than the maximum concurrent discharges or less than the minimum concurrent discharges requires extrapolation of the regressions to ranges where the accuracy is not evaluated. Collectively, the relatively low discharges of WY 2019 and the relatively high discharges of WY 2020 at 15348000 (Fortymile) span a range close to the range of discharges for the nonconcurrent period. The highest daily mean discharge for 15348000 (Fortymile) for the concurrent period was $57,500 \mathrm{ft} 3 / \mathrm{s}$, which was exceeded on 2 days that reached a maximum of $62,700 \mathrm{ft}^{3} / \mathrm{s}$ in the nonconcurrent period. The lowest daily mean discharge for the concurrent period was 809 $\mathrm{ft}^{3} / \mathrm{s}$, greater than discharges for about 2 percent of the nonconcurrent period, which had a minimum of $456 \mathrm{ft} 3 / \mathrm{s}$. Careful interpretation of discharge statistics using the extrapolated discharges at the upper and lower ends of the relation, corresponding to discharges greater than $7,480 \mathrm{ft} 3 / \mathrm{s}$ or less than 187 $\mathrm{ft}^{3} / \mathrm{s}$ at 15330000 (North Fork) and greater than 12,400 ft $3 / \mathrm{s}$ or less than $233 \mathrm{ft} 3 / \mathrm{s}$ at 15331000 (Middle Fork), is advised.

Collectively, these measures indicate that the predictive models using data through WY 2020 have similar or improved accuracy compared to the superseded predictive models using data through WY 2019. The RMSE shows a slight decrease in accuracy for the 15330000 (North Fork) model, but the modified NSEs show improvements in the predictive ability of both models over the Curran (2020) models. However, the addition of larger observed discharges in 2020 reduced the extent of extrapolation at the high end of the range of discharge, improving confidence in the ability of the models to predict the full range of expected values.

Table 4. Root mean square error and modified Nash-Sutcliffe efficiency coefficients for MOVE.3 regression models at two study streamgages in the Fortymile River Basin, Alaska.

[Abbreviation: USGS, U.S. Geological Survey]

\begin{tabular}{ccccc}
\hline $\begin{array}{c}\text { Study USGS } \\
\text { streamgage } \\
\text { number }\end{array}$ & Study streamgage name & $\begin{array}{c}\text { Index USGS } \\
\text { streamgage } \\
\text { number }\end{array}$ & $\begin{array}{c}\text { Root mean } \\
\text { Index streamgage name }\end{array}$ & $\begin{array}{c}\text { Modified Nash- } \\
\text { square } \\
\text { error }\end{array}$ \\
\hline 15330000 & $\begin{array}{c}\text { North Fork Fortymile River above } \\
\text { coefficient }\end{array}$ & 15348000 & $\begin{array}{c}\text { Fortymile River near } \\
\text { Steele Creek, Alaska }\end{array}$ & 0.16 \\
& $\begin{array}{c}\text { Middle Fork near Franklin, Alaska } \\
15331000\end{array}$ & $\begin{array}{c}\text { Middle Fork Fortymile River near } \\
\text { mouth near Chicken, Alaska }\end{array}$ & $\begin{array}{c}\text { Fortymile River near } \\
\text { Steele Creek, Alaska }\end{array}$ & 0.15348000 \\
\hline
\end{tabular}




\section{Summary}

This report, prepared by the U.S. Geological Survey in cooperation with the U.S. Bureau of Land Management, updates and evaluates the accuracy of estimated seasonal discharge records for two streamgage sites in the Fortymile River Basin. Seasonal daily mean discharge records collected in WY 2019-20 for the streamgages, identified for this report as 15330000 (North Fork) and 15331000 (Middle Fork), were extended to provide an additional 20 years of estimated daily mean discharge record for the season May 15-September 30. The extended records were estimated using the MOVE.3 record extension technique and a longer period of record at a single index location downstream of the study streamgages (identified for this report as 15348000 [Fortymile]). The Pearson correlation coefficient between logarithms of concurrent discharge at the study and index streamgages was 0.842 for 15330000 (North Fork) and 0.950 for 15331000 (Middle Fork). Estimates of discharge generated for the concurrent period between the study and index streamgage facilitated an analysis of the accuracy of the estimated record. The modified Nash-Sutcliffe efficiency coefficients for the MOVE. 3 regression models were 0.53 for 15330000 (North Fork) and 0.70 for 15331000 (Middle Fork).

\section{References Cited}

Curran, J.H., 2020, Extending seasonal discharge records for streamgage sites on the North Fork Fortymile and Middle Fork Fortymile Rivers, Alaska, through water year 2019: U.S. Geological Survey Scientific Investigations Report 2020-5003, 11 p., https://doi.org/10.3133/sir20205003.

Curran, J.H., 2021, Extended seasonal discharge records for selected streamgage sites in the Fortymile River Basin, Alaska, 1976-2020: U.S. Geological Survey data release, https://doi.org/10.5066/P9VCAOEZ.

Gibson, W., 2009a, Mean average temperature for Alaska 1971-2000: National Park Service, Alaska Regional Office, Geospatial Dataset-2170516, accessed December 9, 2019, at https://irma.nps.gov/DataStore/Reference/Profile/2170516

Gibson, W., 2009b, Mean precipitation for Alaska 1971-2000: National Park Service, Alaska Regional Office, Geospatial Dataset-2170508, accessed December 9, 2019, at https://irma.nps.gov/DataStore/Reference/Profile/2170508
Granato, G.E., 2009, Computer programs for obtaining and analyzing daily mean streamflow data from the U.S. Geological Survey National Water Information System web site: U.S. Geological Survey Open-File Report 2008-1362, 123 p. 49-89, accessed December 10, 2020, at https://www.usgs.gov/centers/new-england-water/software

Helsel, D.R., and Hirsch, R.M., 2002, Statistical methods in water resources: U.S. Geological Survey Techniques of Water-Resources Investigations, book 4, chap. A3, 522 p., accessed December 10, 2020, at https://pubs.usgs.gov/ twri/twri4a3/

Hirsch, R.M., 1979, An evaluation of some record reconstruction techniques: Water Resources Research, v. 15, no. 6, p. 1781-1790, accessed December 10, 2020. https://doi.org/ 10.1029/WR015i006p01781.

Hirsch, R.M., 1982, A comparison of four streamflow record extension techniques: Water Resources Research, v. 18, no. 4, p. 1081-1088, accessed December 10, 2020. https://doi.org/10.1029/WR018i004p01081.

Krause, P., Boyle, D.P., and Bäse, F., 2005, Comparison of different efficiency criteria for hydrological model assessment: Advances in Geosciences, v. 5, p. 89-97, accessed December 31, 2020. https://doi.org/10.5194/adgeo5-89-2005.

Legates, D.R., and McCabe, G.J., Jr., 1999, Evaluating the use of "goodness-of-fit" measures in hydrologic and hydroclimatic model validation: Water Resources Research, v. 35, no. 1, p. 233-241, accessed December 10, 2020. https://doi.org/10.1029/1998WR900018.

R Core Team, 2020, R-A language and environment for statistical computing: Vienna, Austria, R Foundation for Statistical Computing, accessed December 4, 2020, at https://www.R-project.org/

U.S. Geological Survey (USGS), 2020, USGS water data for the Nation: U.S. Geological Survey National Water Information System database, accessed December 3, 2020, at https://doi.org/10.5066/F7P55KJN.

Vogel, R.M., and Stedinger, J.R., 1985, Minimum variance streamflow record augmentation procedures: Water Resources Research, v. 21, no. 5, p. 715-723, accessed December 10, 2020. https://doi.org/10.1029/ WR021i005p00715.

Williams-Sether, T., and Wheeling, S.L., 2020, Small basin annual yield and percentage of snowmelt runoff in North Dakota, 1931-2016: U.S. Geological Survey Scientific Investigations Report 2019-5144, 37 p., accessed November 27, 2020, at https://doi.org/10.3133/sir20195144. 

Publishing support provided by the U.S. Geological Survey Science Publishing Network, Tacoma Publishing Service Center For more information concerning the research in this report, contact the Director, Alaska Science Center

U.S. Geological Survey

4210 University Drive

Anchorage, Alaska 99508

https://www.usgs.gov/centers/asc/ 
홀 